"Автоматика. Автоматизация. Электротехнические комплексы и системы". Херсон: ХНТУ. №1(25)2010. - С. 26-30.

2. Ю.І. Косенко, П.С. Носов. Механізми ідентифікації та трансформації «знань» суб'єкта критичної інфраструктури // Інформаційні технології в освіті, науці та виробництві. Збірник наукових праць [Текст]. - Вип. 3(4) - Одеса: Наука і техніка 2013, С. 99-104.

3. П.С. Носов, В.Д. Яковенко, Ю.В. Арбузова. Модель професійних знань суб'єктів критичних інфраструктур // Управління проектами: стан та перспективи. Збірник наукових праць за матеріалами IX Міжнародної науковопрактичної конференції. - Миколаїв: НУК 2013. С. 212-215.

4. С.В. Руденко, В.Д. Гогунский. Оценка экологической безопасности в проектах: Монография . - Одесса: Феникс, 2006. - 153 С.

5. Ю.Н. Бардачев, Н.А. Соколова, В.Е. Ходаков / Под редакцией В.Е. Ходакова. Основы дискретной математики: учебное пособие - Херсон: Издательство ХГТУ - 2000. - 356 с.

Статья отправлена: 05.06.2017 г. (C) Дудченко O.M.

\title{
ЦИТ: иа217-073
}

DOI: 10.21893/2415-7538.2017-06-1-073

УДК 004.2

Гарматін В.Д., Максимюк А.В., Цимбаленко Я.Ю. МОДЕЛЮВАННЯ БІЗНЕС-ПРОЦЕСІВ ПІДГОТОВКИ ДОКУМЕНТІВ НА ЗАРАХУВАННЯ ПРАЦІВНИКІВ ДО УНІВЕРСИТЕТУ

Національний технічний університет Украӥни «Київський політехнічний інститут імені Ггоря Сікорського», Киї, проспект Перемоги 37, 03056

Garmatin V.D., Maksymiuk A.V., Tsymbalenko Y.Y. BUSINESS PROCESSES MODELING OF PREPARING DOCUMENTS FOR EMPLOYEES ENROLLMENT TO THE UNIVERSITY

National Technical University of Ukraine "Igor Sikorsky Kyiv Polytechnic Institute", Kyiv, Peremohy Avenue 37, 03056

Анотаиія. Автоматизована інформачійна система «Проект документу» спроектована співробітниками Конструкторського бюро інформаційних систем для вирішення проблем автоматизації відділу кадрів. Модуль «Наказ на зарахування» був розроблений як перма черга системи електронного документообігу. Система значно спростить та пришвидшити роботу з документами, забезпечити їх иұілісне збереження.

Ключові слова: відділ кадрів, підготовка документів, автоматизована система документообігу, Конструкторське бюро інформаційних систем.

Abstract. Automated Information System "Draft document" was designed by Design office of informational systems employees for informatization of human resource department of the university. Module "Order of admission" was created as first stage of document automation. System will greatly simplify and speed up the 
paperwork, provide holistic storage for documents.

Key words: human resources department, document preparation, document automation, Design office of informational systems.

\section{ВСТУП}

На сьогоднішній день інформатизація охоплює коло поточних i перспективних проблем - економічних, організаційних, соціальних, розвиток культури та освіти, діяльності всіх ланок соціального управління, кожної ланки господарювання.

Для успішного розвитку будь-якого підприємства, організації чи установи дуже важливою $є$ організація роботи 3 документами, особливо організація роботи з кадровою документацією.

Для правильного і вчасного прийняття рішення з будь-якого питання керівник установи повинен мати достовірну інформацію про стан особового складу та рух кадрів. Чітка організація обліку особового складу є передумовою успішної аналітичної й оперативної роботи з кадрами на підприємстві, установі чи організації.

В сучасному навчальному закладі кадрове діловодство $\epsilon$ важливим елементом в управлінні персоналом. При цьому ведення обліку кадрів являє собою трудомісткий i тривалий процес, при якому необхідно постійно враховувати особливості Трудового законодавства і постійно відслідковувати законодавчі зміни. Для вирішення цієї проблеми потрібна правильна організація, інформатизація та механізація роботи персоналу.

В КПІ ім. Ігоря Сікорського (далі - університет) працівниками КБ інформаційних систем була розроблена перша черга електронної системи документообігу, а саме, модуль «Наказ на зарахування» автоматизованої інформаційної системи «Проект документу». Від ефективності системи «Проект документу» залежить ефективність всієї роботи університету, оскільки документи забезпечують інформаційну підтримку прийняття управлінських рішень на всіх рівнях і супроводжують всі бізнес-процеси. При неправильній організації роботи 3 вхідною та вихідною документованої інформацією університет може понести істотні збитки у часі, так як це може сильно загальмувати, або навіть паралізувати його роботу.

\section{ПОСТАНОВКА ЗАДАЧІ}

Провести аналіз предметної області та спроектувати, за допомогою методології SADT, функціональну модель автоматизацій процесу підготовки документів для зарахування працівників на роботу до університету.

Спроектувати по проведеному аналізу наступні моделі представлення бізнес-процесів:

- Контекстну діаграму;

- Функціональну декомпозицію;

- Діаграму інформаційних потоків.

Розробити модуль «Наказ на зарахування» автоматизованої інформаційної системи «Проект документу» який матиме зручний інтерфейс та буде надавати найбільш гнучкий спосіб перегляду, додавання, редагування та видалення даних. При функціонуванні даної автоматизованої інформаційної системи має 
здійснюватися контроль вхідної та вихідної інформації, в тому числі даних, що вводяться користувачем і даних, що містяться в таблицях баз даних. У разі помилки введення-виведення повинні видаватися відповідні повідомлення i надаватися можливість виправлення помилок i продовження роботи. При виконанні операцій по зміні або видалення даних необхідно забезпечити цілісність БД.

\section{Функціональне проектування модуля «Наказ на зарахування»}

Для вирішення поставлених задач був проведений аналіз процесів документообігу університету, де була виявлена можливість раціоналізації його за рахунок зменшення дублюючої інформації.

В результаті проведеного аналізу предметної була спроектована контекстна діаграма «Оформлення працівника на роботу» (рис.1).

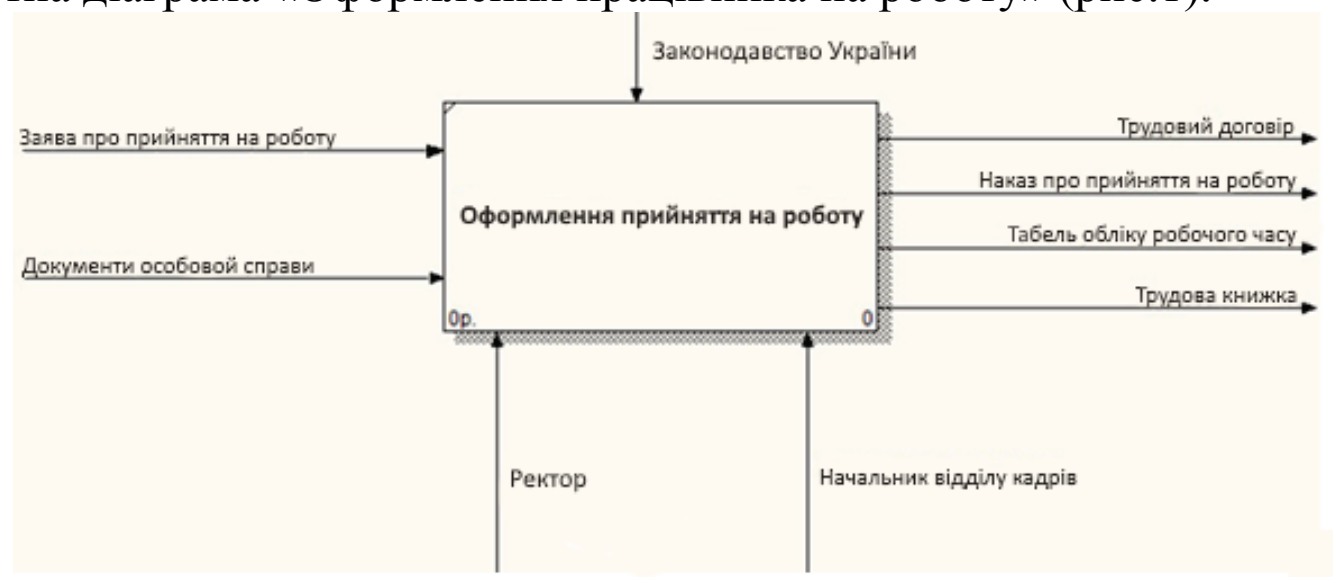

Рис. 1. Контекстна діаграма «Оформлення на роботу»

Стратегії та процедури, якими керується процес (управління) Конституція України [1], КЗПП України [2], а також інші чинні законодавчі акти України.

Вхідною інформацією для модуля «Наказ на зарахування» $є$ відділи, посади, ставки, оклади і т.д. Введення вхідної інформації здійснюється працівником відділу кадрів. Вихідною інформацією для системи є вихідні документи.

Функціональна декомпозиція системи, наведена на (рис. 2).

Впроваджувати автоматизацію необхідно на всіх етапах діловодства, починаючи $з$ підготовки документів. Діаграма інформаційних потоків модулю «Наказ на зарахування» за методологією DFD, наведено на (рис. 3).

Розподілена архітектура системи управління документами, повинна відповідати наступним вимогам:

1. Масштабованість, надійність і керованість для економічного корпоративного розгортання. Це означає, що можна починати впровадження системи покроково, а потім нарощувати до рівня підприємства й за його межі як корпоративну технологію управління документами.

2. Автоматична підтримка розподіленого управління різними інформаційними матеріалами протягом їхнього життєвого циклу - від авторської розробки, створення, рецензування, узгодження, затвердження в інтерактивному режимі до розповсюдження й архівування. 


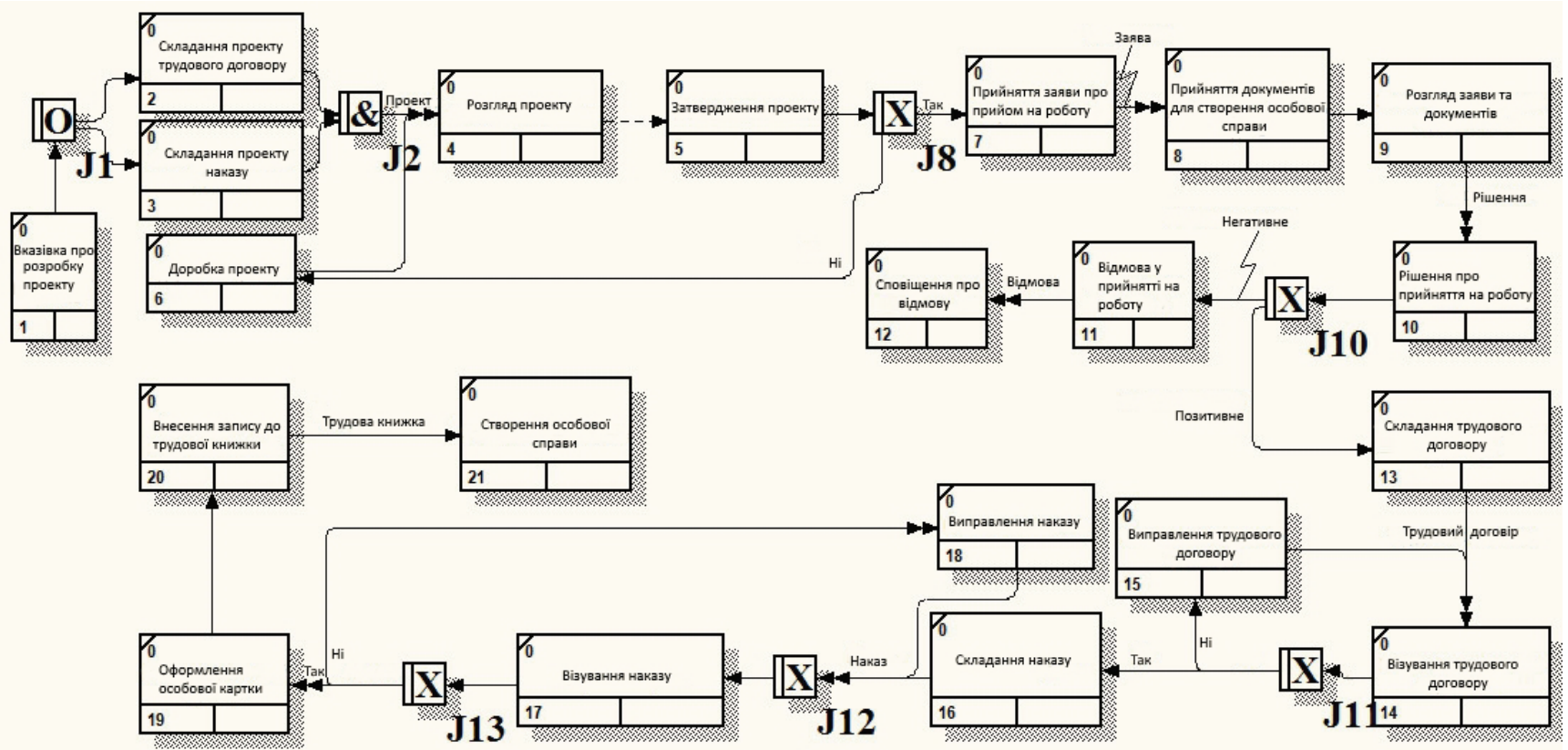

Рис. 2. Функціональна декомпозиція системи

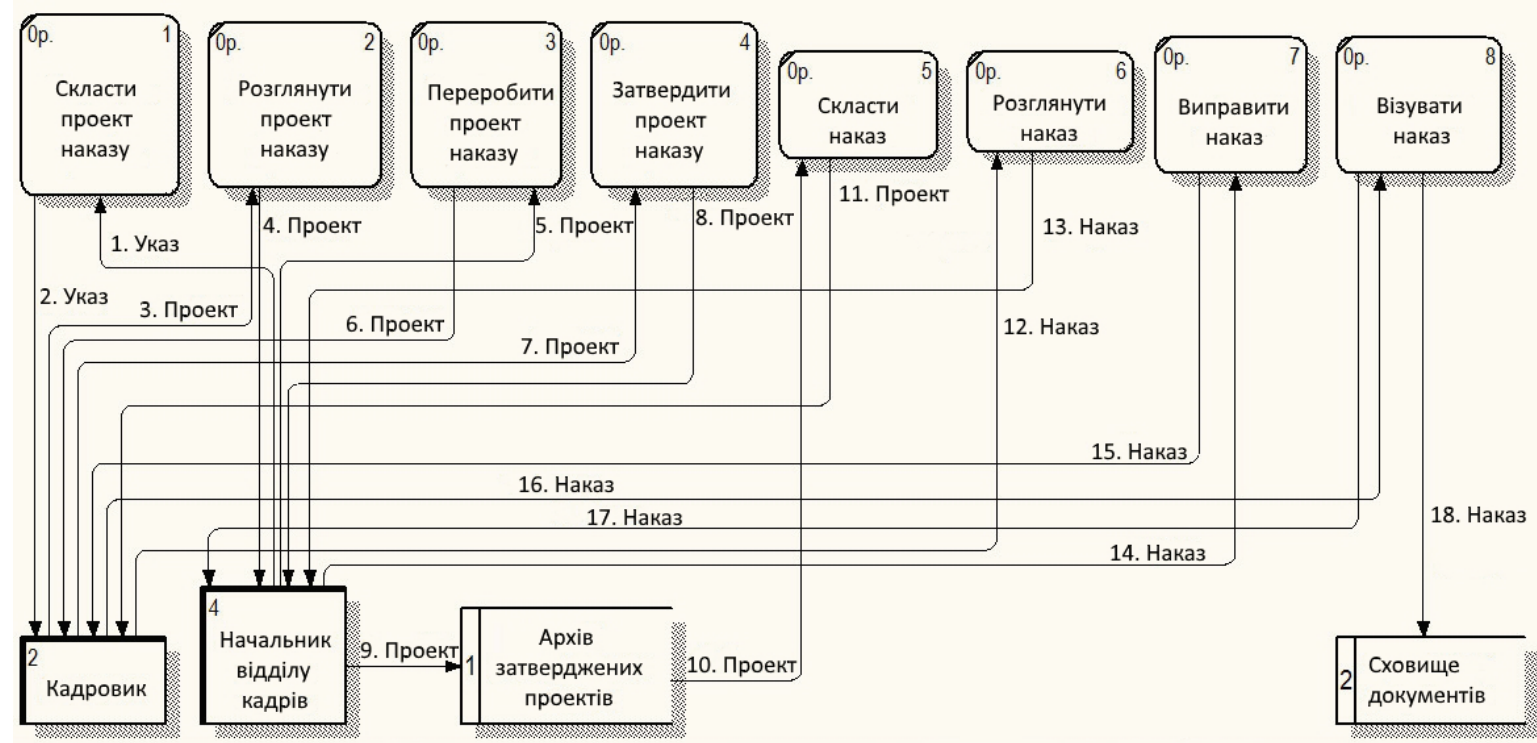

Рис. 3. Діаграма інформаційних потоків

3. Гнучкість управління доступом до всього спектра документів: текстових, формалізованих документів, образів документів, електронних таблиць, аудіо-, відеоданих, документів Web, електронної пошти, дискусійних баз даних.

4. Відкрита, розширювана архітектура, що дозволяє швидко розширювати платформу системи управління документами у відповідь на появу нових бізнесцілей, а також інтегрувати систему управління документами 3 бізнес-додатками ERP-системи, CRM-системи, системи управління знаннями.

На базі розроблених бізнес-процесів була спроектована архітектура системи модуля «Наказ на зарахування», яка включає в себе складові (рис. 4):

- Основна частина документу;

- Підписує документи;

- Погоджує документи; 
- Документи готували;

- Розсилка;

- Друк.

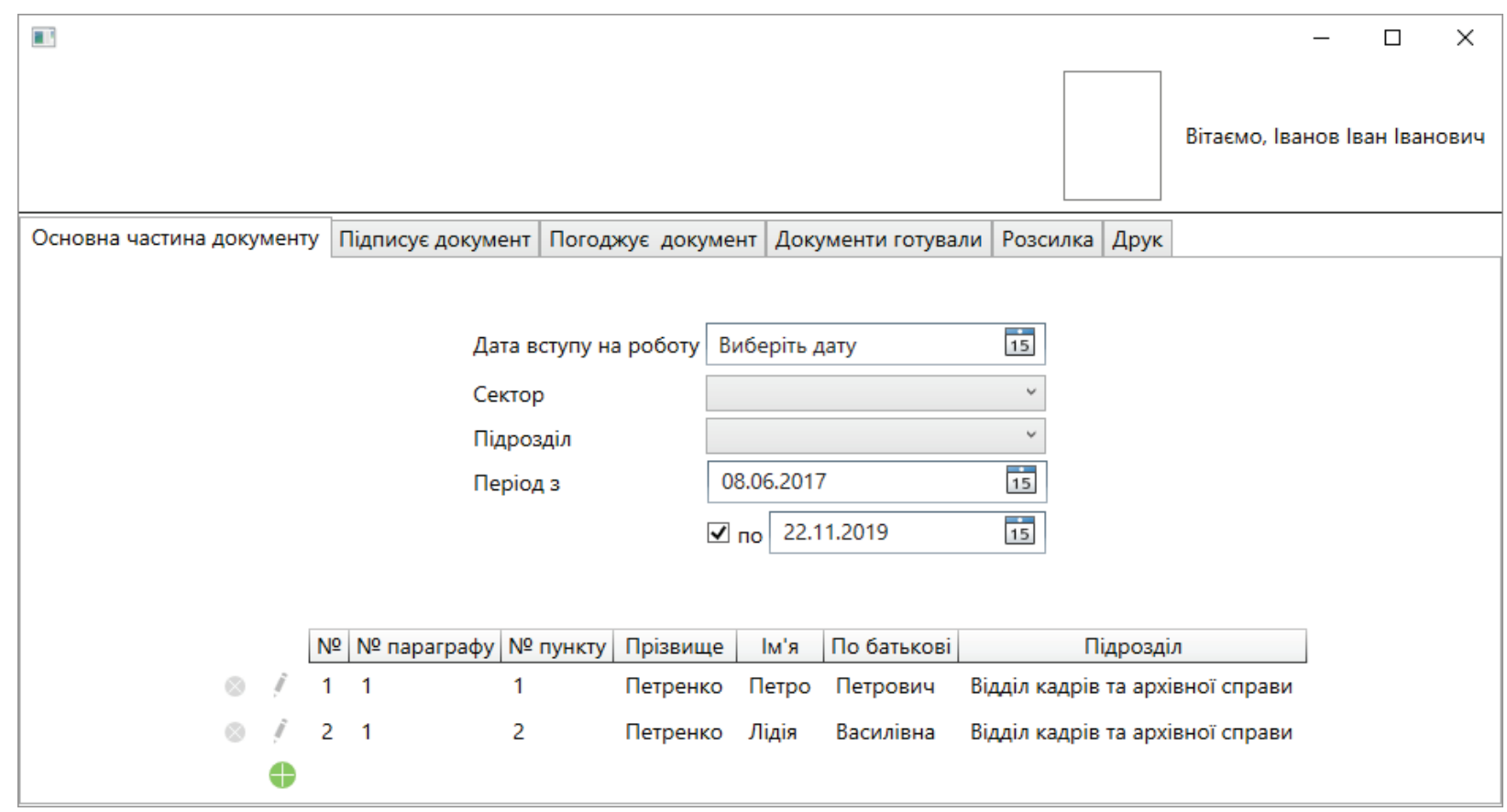

Рис. 4. Інтерфейс модулю «Наказ на зарахування»

\section{ВИСНОВКИ}

Модуль «Наказ на зарахування» автоматизованої інформаційної системи «Проект документу» розроблений з метою удосконалення управління, збору, реєстрації, передачі, накопичення, пошуку, обробки та захисту документів 3 використанням сучасних технологій, а також дозволяє:

- уникнути проблеми відстані і швидкості передачі інформації;

- уникнути проблеми дублювання документів, так як все зберігається в єдиній базі;

- збільшити ефективність і швидкість пошуку документів;

- легко проконтролювати своєчасність виконання розпорядження керівника по конкретному документу;

- відслідковувати та адаптуватись до змін в чинному законодавстві; України.

- контролювати та запобігати порушенням трудового законодавства

\section{СПИСОК ВИКОРИСТАНИХ ДЖЕРЕЛ}

1. Конституція України від 28.06.1996 р.:- Режим доступа: http://zakon2.rada.gov.ua/laws/show/254-вр

2. Кодекс законів про працю України від 10.12 .71 р.:- Режим доступа: http://zakon2.rada.gov.ua/laws/show/322-08

Стаття відправлена: 08.06.2017 p.

(C) Гарматін В.Д., Максимюк А.В., Цимбаленко Я.Ю. 